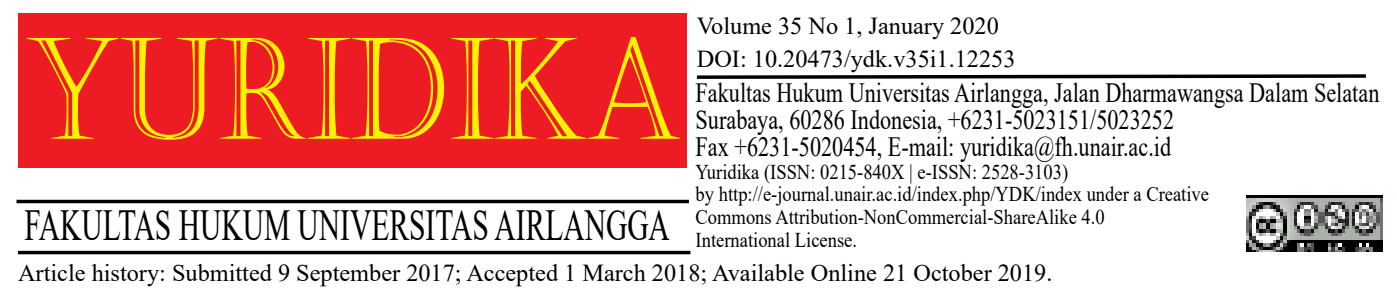

\title{
The Position of Justice Collaborator to Reveal Corruption in Financial Management of Regional Government
}

\author{
Nurma Rosyida, Kadek Deddy Permana Artha and Lintang Yudhantaka \\ nurmarosyida@gmail.com \\ District of Public Prosecutor East Nusa Tenggara
}

\begin{abstract}
Regional autonomy that Indonesia government has implemented gives an authority to the regional government to manage their governmental affairs, including those related to their local financial management. This authority, however, is not well organized. Recently, corruption is increasingly found in local financial management, and it involves many parties within. To overcome such issue, the law enforcers may consider justice collaborator to define who the real culprit is, and thus, it needs particular criteria that refer to corruptors in the financial management of regional government. Therefore, this paper aims to analyze the key actor of corruption in the financial management of the regional government to determine justice collaborator. Using statute, conceptual, and case approaches, it finds that to determine the justice collaborator, it should identify the culprit. The criteria of corruptor in the financial management of regional government involve having a high position and dominant (influential) roles in making the crime happen, and may stop or continue the crime. Keywords: Justice Collaborator; The Primary Culprit; Financial Management of Regional Government.
\end{abstract}

\section{Introduction}

The Republic of Indonesia is divided into provincial regions which also have many sub-regions and cities for each, which all of those have their local government. It corresponds to Article 18 subsection (1) of the Constitution of the Republic of Indonesia 1945 (i.e., UUD NRI 1945). Since the implementation of Law No. 32/ 2004 which has been amended by Law No. 23/ 2014 about Local Government (i.e., Law of Local Government), Indonesia applies regional autonomy system, that makes each of the regions has an authority to manage and govern their internal affairs. One authority by local government deals with financial management. It is supported by the provision of Article 6 subsection 
(2) letter (c) of Law No. 17/ 2003 about Regional Finance (i.e., Law of Regional Finance), through which the President, as the supreme leader of national financial management, delegates the regional governments to manage their local finance and represents the regional government in the ownership of separated regional assets. Article 1 subsection (6) of Government Regulation No. 58/ 2005 about Financial management of regional government (i.e., PP 58/2005), mentions that financial management of regional government involves all of the activities such as planning, executing, administering, reporting, accounting, and monitoring the regional finance. However, the authority is not compensated with competence to manage the regional finance, causing the practice of corruption happens during the process of financial management of regional government.

Syed Hussein Alatas defines three stages of corruption, as follow. ${ }^{1}$

a) The stage at which corruption is relatively restricted without affecting a wide range of social life. In this stage, the mandate is well conducted and thus no corruption is found in the government;

b) The second stage is where corruption becomes rampant and all-pervading. In this stage, each of the government activities has utilized the national finance, and the practice of corruption is found, both in central and regional government;

c) The third stage of corruption is the most interesting, and at times most difficult to notice. In this stage, corruptions have been increasingly massive, which may ruin many sectors of life.

With the stages by Syed Hussein Alatas, it is clear that corruption in a state begins on which the state uses the state budget, as well as in provincial, regional, and sub-regional governments. Since the implementation of regional autonomy, each of the regions has the authority to use their local budget to support each of their locally governmental activities.

Since the Committee of Corruption Eradication is held (i.e., KPK) up to 2018, Anti Corruption Clearing House of KPK (i.e., ACCH KPK) has found

1 Haryono Umar, Corruption the Devil (Universitas Trisakti Jakarta 2016).[105]. 
128 corruptions in provincial government and 295 corruptions in regional governments, and unfortunately, the number keeps increasing every year. Based on the data, provincial and regional governments get the second and third ranks as ones with the biggest number of corruption in Indonesia. ${ }^{2}$ The incessant effort of government through KPK to eradicate corruptions, however, does not make the culprit afraid and stop corrupting. Otherwise, corruption in Indonesia has been recently in the red line since corruption, collusion, and nepotism are found in almost each of the instances with a variety of motives, more structural, and involving many parties. ${ }^{3}$

Huge corruption happens in the highest level of government involving particular projects and key programs of government. ${ }^{4}$ Corruption is a dependent crime that needs other parties or even a broad network, and thus, it is classified into organized crime. Corruption overcome through litigation often finds that such crime is conducted by more than one party (organized). ${ }^{5}$ Corruption cases revealed in Indonesia are identified as organized corruptions, not single, and those involve many parties and have a certain pattern. ${ }^{6}$ Corruption occurs with a variety of motives and supports from many parties. This crime is by design and neat on its conceptual draft of development budgeting and operational planning. With good preparation on the implementation of development, corruption may happen neatly without being found by the law. Corruption by design may bring out practices that injure the state. Composing projects for development is not set professionally and people-oriented, but solely set by "project sharing" approach. ${ }^{7}$

\footnotetext{
2 Anti Corruption Clearing House Komisi Pemberantasan Korupsi, 'Tindak Pidana Korupsi Berdasarkan Instansi' (Anti Corruption Clearing House Komisi Pemberantasan Korupsi, 2016) $<$ https://acch.kpk.go.id/id/statistik/tindak-pidana-korupsi/tpk-berdasarkan-instansi> accessed 25 February 2018.

3 Nur Basuki Minarno, 'Pembuktian Gratifikasi Dan Suap Dalam Tindak Pidana Korupsi' (2005) 20 Yuridika.[103].

4 Susan Rose-Ackerman, Korupsi Dan Pemerintahan (Translator: Toenggoel P. Siagian ed, Pustaka Sinar Harapan 2010).[37].

5 Basir Rohrohmana, 'Penerapan Ajaran Turut Serta Dalam Tindak Pidana Korupsi' (2017) 32 Yuridika.[211].

6 Alfitra, Modus Operandi Pidana Khusus Di Luar KUHP (Korupsi, Money Laundering Dan Trafficking) (Raih Asa Sukses 2014).[3]

7 ibid.[12].
} 
Therefore, it needs extensive prevention that covers various aspects of national and governmental organization that, indeed, are very sensitive to corruption, from petty to big fish levels. ${ }^{8}$ In high level, many parties are often found engaged in the crime, and it provokes a question "who is the real culprit?" it is more difficult to identify in case that the corruption happens in regional government in term of its financial management as it involves Regional Head, Management Unit of Regional Finance (i.e., SKPKD), the Head of Regional Officials (i.e., SKPD), Regional Secretary, and Legislative Assembly of Regional Government (i.e., DPRD) that each of which has different authority in financial management of regional government. In the process of handling a case of corruption, the law enforcers usually use another suspect out of the real culprit to reveal the party behind the crime. Such a method is called justice collaborator. The existence of justice collaborator is set under Article 37 subsection (2) of United Nation Convention Against Corruption 2003 (i.e., UNCAC 2003), as ratified through Law No. 7/2006 (i.e., UU 7/ 2006). Defining an individual as justice collaborator should be wisely considered to ensure that he/she who gets dispensation due to becoming justice collaborator is not the intellectual narrator behind the corruption case, while the subordinates that play small roles are charged more severely. To determine the justice collaborator, therefore, it needs particular criteria to define the key actor behind the corruption case. By the description, the legal issue discussed here is the key actor of corruption in the financial management of the regional government to determine the justice collaborator.

\section{Corruption in Financial Management of Regional Government}

The legal provision of corruption eradication currently applied is Law No. 31/1999 about Corruption Eradication as amended by Law No. 20/2001 about the amendment of Law No. 31/1999 about Corruption Eradication, further called UU PTPK. The crime of corruption involves either public officials or civil servants that have tight relation with authority misuse by the officials. This misuse of authority

${ }^{8}$ Haryono Umar (n 1).[142]. 
is the key element of corruption. The element of authority misuse is identified as "bestanddeel delict" (i.e., the core part of delict), and it must always be in the element of corruption delict although using different wording, ${ }^{9}$ such as the bribery, gratification, or blackmailing to and/or by government apparatus. Indriyanto Seno Adji defines authority misuse in administrative law as follow.

1. Authority misuse for crimes against public interests that may give benefits to either personal, collective, or group interests;

2. Authority misuse in terms that the action is actually proposed for public interests, however, the aim is then out of the track from what the authority is actually assigned by law or other regulations;

3. Authority misuse in terms of misusing the procedures that should be implemented for particular purposes; otherwise, it uses another procedure to be implemented. ${ }^{10}$

To appraise whether or not there is the misuse of authority, it should initially identify whether the authority is classified into either imbeded or discrete authority. Following H. Sadjijono, the imbeded authority refers to the authority that should correspond to the basic rule which determines time and condition through which the authority is implemented, including the basic draft of the content and decision to be made. ${ }^{11}$ In this case, there is a basic rule that regulates in detail the condition under which the authority is implemented. The condition is compelling for government officials to implement their authority, and it is obligatory. ${ }^{12}$ The authority of investigators to stop the investigation is one of the instances. This ceasing of investigation belongs to the investigators' authority, as mentioned in Article 109 subsection (2) of Law No. 1/1946 about Legal Regulation jo. Law No. 73/1958 stating the application of Law No. 1/1946

\footnotetext{
9 Nur Basuki Minarno, Penyalahgunaan Wewenang Dan Tindak Pidana Korupsi Dalam Pengelolaan Keuangan Daerah (Laksbang Mediatama 2009).[7].

${ }^{10}$ Abdul Latif, Hukum Administrasi Dalam Praktik Tindak Pidana Korupsi (Prenada Media Group 2014).[38].

${ }_{11}$ H. Sadjijono, Bab-Bab Pokok Hukum Administrasi (LaksBang Pressindo 2011).[59].

12 ibid.
} 
about Legal Regulation of Crime for Every Region of the Republic of Indonesia and Altering the Criminal Code (i.e., KUHP), since the investigator may stop the investigation under several conditions, as follows.

a. The case is not classified into crime;

b. No adequate evidence that refers to the element of the crime; or

c. The suspect passes away

In case that one of those three criteria is met, the investigator is authorized to stop the investigation. In the juridical system perspective, this imbeded authority is classified into general authority based on legislation that regulates how instances or administrative officials implement their authority. This imbeded nature refers to the existence of rules (either norms or regulations) that should be complied to implement an authority. ${ }^{13}$

Discrete authority assigned to government officials or instances (administrative) makes them free to determine the content of decision to be made since the basic rules of this authority provide independence for the authorized. For instance, police officers may determine whether or not a suspect can be shot in which the suspect is caught. Such action is based on the discrete decision from the police officers who execute the arrestment. The decision to do particular action is based on their own independent Evaluation. Hence, it is called a discrete authority. ${ }^{14}$

Although the government has this discrete authority, they may not use it arbitrarily since there is no absolute authority in this law state. Authority should always be implemented under a set of legal boundaries, given that it is only provided by legislation and derives from the applied regulation. Therefore, the legitimation of organizing a government is the authority by law (authority norms), and the substances of legality in organizing a government are an authority. ${ }^{15}$

Misusing an authority may not be conducted by a party with no power/ prominent position. Thus, the principle of legality constitutes the basis of

\footnotetext{
13 ibid.

14 ibid.[60].

15 ibid.[61].
} 
legitimation for the government to do some actions for a purpose. An authorization to government officials, in particular to civil servants, is assigned by regulation set under Law No. 30/2014 about Government Administration (i.e., UU 30/2014). Based on this act, authority misuse is classified into three categories, as follow.

1. Beyond an authority, in case that the decision and/or action to conduct:
a. Beyond the tenure or has been expired;
b. Beyond the boundaries the authority applies;
c. Against the regulation.

2. Confounding the authority, in case that the decision and/or action to conduct:
a. Out of the scope or content of the authorized authority; and/or
b. Against the purpose of the authority.

3. Acting arbitrarily, in case the decision and/or action to conduct:
a. Has no basis of authority; and/or
b. Against the court verdict which has fixed legal power.

The legal enforcers investigate and valuate whether or not a misuse of authority in the government field. At first, what they need to take into account is whether or not the regulation provides an authority about such issue, and whether the deed is against the purpose of the authority. In the Decree of the Supreme Court of the Republic of Indonesia No. $223 \mathrm{~K} / \mathrm{Pid} / 2002$ on $11^{\text {th }}$ July 2002, the parameter to measure the misuse of authority is the principle of legality (i.e., written rules) that refers to Regional Regulation and Regent Decree. Along with the Decree of the Supreme Court, the Decree of the Supreme Court of the Republic of Indonesia No. $380 \mathrm{~K} / \mathrm{Pid} / 2001$ on $10^{\text {th }}$ March 2001, the panel of judges on their ratio decidendi states that any action from the defendant against the Decree of President, the Decree of Minister of Finance of the Republic of Indonesia, and the Collective Decree between the Board of Bank Indonesia and Head of National Banking Recapitalization (i.e., $\mathrm{BPPN})$ refers to an authority misuse. However the implementation of legislation -out of regional regulation and law- that is used as the basis to define the crime is still debatable about whether or not it is against the principle of legality. The first argument suggests that legislation, out of regional regulation and law, is used as the 
basis to reveal the misuse of authority, and UU PTPK is used as the basis to sue the crime. Another argument claims that the violation against the law, out of regional regulation and law, may not be used as the basis to sue a suspect/defendant. ${ }^{16}$ In corruption case, related with Article 2 UU PTPK the basic evidence is that there are unlawful act must be referred to the decision of Constitutional Court No. 003/ PUU-IV/2006 on July $24^{\text {th, }} 2006$ related to the unlawful act in the article 2 UUPTK limit the "unlawful act" term itself, the existence of the unlawful act in this article is not as kernbestanddeel (core element), but only used as tools to point toward the prohibited actions, that is the act of enriching oneself, or someone else, or a corporation. ${ }^{17}$ Whereas for the abuse of authority, the benchmark for determining whether or not an abuse of authority is not only referred to legislation but can also refer to decision authority of the party charged with a criminal offense as referred to in Article 3 of UUPTPK.

Financial management by the regional government in the form of regional budgeting should be implemented in neat, effective, efficient, economical, transparent, and responsible way, as well as under a set of regulation by considering the principle of fairness, propriety, and benefits for people. In a case that it does not match, the process of regional budgeting will be seen as a gate for many parties to do corruption. The process of budgeting applied by Indonesia based on PP $58 / 2005$ is a bottom-up process, in which the regional head involves the regional secretary, SKPD, and public. However, public involvement is not well implemented yet because the process of public participation is not considered as the process of negotiation but merely socialization and information sharing to the public. From the beginning process, they do not engage the public to participate within, but solely socializing the result of the structured plan they have made. ${ }^{18}$

\footnotetext{
${ }^{16}$ Nur Basuki Minarno (n 9).[181].

17 Shinta Agustina, Penjelasan Hukum Unsur Melawan Hukum: Penafsiran Unsur Melawan Hukum Dalam Pasal 2 Undang-Undang Pemberantasan Tindak Pidana Korupsi (Lembaga Kajian dan Advokasi Independensi Peradilan 2016).[16].

18 Sekretariat Nasional Forum Indonesia untuk Transparansi Anggaran, 'Korupsi (Sudah) Terjadi Sejak Perencanaan Anggaran' (Seknas Fitra) < http://seknasfitra.org/korupsi-sudah-terjadisejak-perencanaan-anggaran/> accessed 25 February 2019.
} 
Started from the implementation of SKPD forum to organize RKA-SKPD, it is seen as a chance to put particular interests through negotiation, whether or not the program they have planned corresponds to Regional Medium-Term Development Planning (i.e., RPJMD). It is similar to the process of drafting General Rules of Budget (i.e., KUA) and the Priority of Temporary Budget Limit (i.e., PPAS) by the regional secretary to be filed to the regional head as the basis to set regional budgeting (i.e., APBD). ${ }^{19}$ Practices of corruption are often found during this process. First, it happens by marking-up the amount of budget by designing the standard of price and budgeting higher than the market price. In this case, corruption may happen although the project has corresponded to the planning of development. Furthermore, corruption may happen by mentioning the volume of basic needs higher than the actual needs. Second, it happens by allocating an unreasonable budget for "fictitious" programs such as maintenance budget for a governor's new car at IDR 368.000.000 per year. This amount is almost similar to the price of purchasing the car. Another corruption is by manipulating the budgeting, such as having a huge amount of retirement. Preventing any spotlight from public, the corruptors manipulates the budget with another title such as budget for life insurance with unreasonable premium. ${ }^{20}$

Those various manipulations on budgeting show that corruption indeed happens in the stage of budgeting. In the implementation of development projects, there are many motives of corruption, as follow.

a. Collusion between enterprises and government in deciding ones winning particular tender of a development project. To win the tender, the enterprise must bribe several related stakeholders.

b. Using coercion in which the giver is forced to bribe to prevent any possible disadvantages that may threaten their individual and collective interest, as well as the other valuable things they may have. For instance, a leader of a project, either directly or indirectly, is under pressure to transfer some money
19 ibid.
20 ibid.[17-19]. 
to his employer, unless he may lose an opportunity to become the leader of the subsequent projects. ${ }^{21}$

Thus, corruption in the financial management of regional government has existed since the process of regional budgeting up to the procurement of government goods and services, both in provincial and sub-regional level.

\section{Justice Collaborator and the Criteria of Key Actor of Corruption in Regional}

\section{Finance}

The meaning number of crime demands extra effort, especially those related to organized crimes such as corruption. In an international setting, an attempt to eradicate such organized crime is by providing specific treatment to the secondary actor to be cooperative with the law enforcers. It is called a justice collaborator. The urgency of justice collaborator is as means to thoroughly reveal the crime, since it needs information about the real culprit to reveal an organized crime such as corruption, as well as the structure of crime related to who is actually behind such crime, the activities, and the cash flow which is often difficult to be found due to its confidentiality by the organized group. On the other hand, the fundamental role of justice collaborator is revealing the practice of crime, given that judicial apparatus often encounter several juridical and not-juridical obstacles in thoroughly investigating and revealing a crime. ${ }^{22}$ One of the obstacles they may encounter is the status of the corruptors as ones with high position and/or extensive insight (i.e., white-collar crime/intellectual crime). Thus they have access to make any evidence of their crime disappear and cover up their crime along with their corruptive network. ${ }^{23}$ Hence, the investigators should do their best to uncover the network by utilizing the secondary actor of the crime. The actor is asked to be cooperative to reveal the real culprit that plays more roles on corruption he/she made.

\footnotetext{
${ }^{21}$ ibid.

${ }^{22}$ Firman Wijaya, Whistle Blower Dan Justice Collaborators Dalam Perspektif Hukum (Wedatama Widya Sastra 2014).[19]. Hukum.[46].

3 Mudzakkir, 'Penyelesaian Kejahatan Yang Termasuk White Collar Crime' (1994) 2 Jurnal
} 
In the 1970 s, the United to endeavored to uncover an organized crime by the Italian mafia. However, the mafia has a code of silence called Omerta. ${ }^{24}$ It was the first step of how American government saw the practice of protection for every witness that cooperated as justice collaborator who had a good faith and willing to uncover and eradicate an organized crime that involved many parties. ${ }^{25}$

The practice of corruption acts that often occur in our society involves more than one perpetrator, which is known as inclusion or deelneming. This participation is known as all for participating acts both psychologically or physically by a person, or even more. ${ }^{26}$ Van Hamel defines this kind of participation as the responsibility doctrine in a criminal act that by the law can be carried out by an actor with his actions. ${ }^{27}$ Participation questions about whether or not there is a relation between each actor in an implementation of a crime or delict, what kind of role that each actor performs so that the crime can be carried out or resolved, and the actor's responsibility for his involvement in a crime. ${ }^{28}$ This act of involvement stated by article 55 and article 56 of KUHP:

\section{Article 55}

(1) As principals of a punishable act shall be punished:

$1^{\text {st }}$, those who perpetrate cause others to perpetrate, or take a direct part in the execution of the act;

$2^{\text {nd }}$, those who intentionally provoke the execution of the act by gifts, promises, abuse of power or respect, force, threat, or deception or by providing an opportunity, means or information.

\footnotetext{
${ }^{24}$ Lilik Mulyadi, Perlindungan Hukum Whistleblower and Justice Collaboration Organized Crime (Alumni 2015).[5].

${ }_{25}$ Barda Nawawi Arif, Bunga Rampai Kebijakan Hukum Pidana (Citra Aditya Bakti 1996). [107-108].

26 Endi Nurindra Putra, 'Penerapan Ajaran Penyertaan Dalam Tindak Pidana Kecelakaan Lalu Lintas Yang Dilakukan Oleh Anak (Studi Perkara Di Wilayah Hukum Pengadilan Negeri Purworejo)' (2015) 1 Jurnal Idea Hukum.[20].

27 Ike Indra Agus Setyowati, 'Pembantuan Dan Penyertaan (Deelmining) Dalam Kasus Perkosaan Anak’ (2018) 1 Media Iuris <https://e-journal.unair.ac.id/MI/article/view/8831>.[284].

${ }_{28}$ Ahmad Rifai Rahawarin, 'Delik Penyertaan Dalam Tindak Pidana Korupsi Ditinjau Dari Perspektif Pemberantasan Korupsi Di Papua (Study Kasus Nomor: 69/Tipikor/2013/PN-JPR)' (2014) 4 Legal Pluralism.[235]
} 
(2) In respect to the provoker only those acts which have been deliberately provoked and their consequences shall be considered.

Article 56

As Accomplices to a crime shall be punished:

$1^{\text {st }}$, the persons who deliberately aid in the commission of the crime;

$2^{\text {nd }}$, the persons who deliberately provide the opportunity, means or information

for the commission of the crime.

In Indonesia, the position of justice collaborator is relevant to the Indonesia judicial system to overcome the procedural stagnation in a crime which evidence is difficult to be found. ${ }^{29}$ It is implemented after ratifying UNCAC 2003, in which Article 37 subsection (2) UNCAC 2003 mentions that "each state party shall consider providing for the possibility, in appropriate cases, of mitigating punishment of an accused person who provides substantial cooperation in the investigation or prosecution of an offense established in accordance with this convention". This provision is mentioned in a mutual decree among Organization of Protection for Witness and Victim (i.e., LPSK), Attorney General, the Police of the Republic of Indonesia, KPK, and Supreme Court. The provision mentions that justice collaborator is a witness who is also the actor of the crime and willing to cooperate with law enforcer to reveal a case and even give back the assets he/she corrupted in case that it is on him/her. ${ }^{30}$ In addition, the provision related to justice collaborator in Indonesia is mentioned in Law No. 13/2006 about the Protection for Witnesses and Victims as amended by Law No. 31/2014 about the Amendment of Law No. 13/2006 about the Protection of Witnesses and Victims, further called UU LPSK, as well as regulated under the Circular Letter of the Supreme Court of the Republic of Indonesia No. 4/2011 (i..e, SEMA 4/2011) about the Treatment for Wistleblower and Witnesses who cooperate with law enforcers as justice collaborator to reveal particular crime.

SEMA 4/2011 sets the basis to determine who becomes a justice collaborator, as follow.

\footnotetext{
${ }^{29}$ Firman Wijaya (n 22).[19-20].

${ }^{30}$ Lilik Mulyadi (n 24).[4].
} 
1. The crime to be uncovered is a serious and organized crime such as corruption, the violation against fundamental human rights, drugs, terrorism, money laundry, trafficking, and forestry. Also, it does not recognize justice collaborator in light crime;

2. The information shared is significant, relevant, and reliable. It may become a hint for the law enforcers to reveal a crime and help their performance;

3. Individuals that become justice collaborator is not the primary actor of the crime since his/her presence as justice collaborator aims to uncover the primary actor of the crime;

4. $\mathrm{He} / \mathrm{she}$ admits his/her crime in front of justice and be willing to return the assets he/she has corrupted;

5. The public prosecutor, in his/her prosecution, claims that the pertinent party provided significant information and evidence to help the investigators and public prosecutor to reveal the crime ineffective way, uncovering other actors behind the crime who play more roles and/or return any assets they have corrupted.

According to the explanation of SEMA 4/2011, a question reveals what is the criteria of being the primary actor of corruption in regional finance. Given that corruption refers to organized crime, the corruptors are more than one party with different roles to play. To determine the primary actor of corruption, especially in regional finance, it needs to consider several criteria, as follow.

1. The primary actor of corruption has high position;

2. The primary actor of corruption has a dominant (the most influential) role to make the corruption happen; and/or

3. The primary actor of corruption may stop or continue his crime of corruption.

The first criteria are having a high position in a particular field. One with the high position is very identic with authority embedded on him to lead a governmental instance, such as in regional setting as like Regional Head or the Head of Regional legislative assembly or other functions with the extensive authority set under certain regulations and basic governmental norms. With high position embedded on him, he may have dominant control over every decision in pertinent instances, in which the decision related to government setting is on his hand. In the literature of administrative law, there are two methods to get a government authority; attribution and delegation. Sometimes, however, the mandate is another case to 
get an authority. ${ }^{31}$ Attribution is related to the assignment of the new authority, and delegation deals with bestowing an existing authority (by an authorized party which authority derives from attribution toward another party). Logically, delegation is always preceded by attribution. ${ }^{32}$ Nur Basuki Minarno argues that a shift may happen from a mandate to the pseudo delegation, and it is identified as smuggling of law, which practice is similar in every region. ${ }^{33}$ For instance, in Surabaya municipality, a letterhead entitled "Regional Building Supervision Service" is established to organize a license of Building (i.e., IMB), and no longer use letterhead from the Mayor of Surabaya. This shift seems as if the authority had been delegated to the Regional Building Supervision Service.

Given that the position of the service head is under the Mayor, it is impossible to conduct such authorization as the service head is the subordinate of the Mayor. ${ }^{34}$ Either partly of thorough delegation by a Mayor to regional secretary may not be classified into delegation as the secretary is Mayor's subordinate/assistant. Toward pseudo delegation, it may create an issue in terms of administrative law related to the Decree of State Administration (i.e., KTUN) to whom the lawsuit is filed, as administrative law sees the position of a regional head as a stakeholder that represents regional government, both in external and internal affairs.

It is different from the criminal setting, one who should be responsible for mandate or delegation in criminal law is one who gives the mandate or delegation, given that criminal law recognizes what is called personal responsibility. In financial management of regional government, for instance, the Mayor misuses his authority, which may imply corruption, and thus he should take personal responsibility. Toward corruptor's responsibility, it needs to distinguish between functional liability and personal responsibility, as applied in criminal law. ${ }^{35}$

31 Pilliphus M. Hadjon, 'Tentang Wewenang' (1997) 7 Yuridika <https://e-journal.unair. ac.id/YDK/article/view/5769>.[1].

${ }^{32}$ H. Abdul Latif, Hukum Administrasi Dalam Praktik Tindak Pidana Korupsi Edisi Kedua (Kencana 2014).[14].

${ }^{33}$ Nur Basuki Minarno (n 3).[72].

${ }^{34}$ ibid.

${ }^{35}$ H. Abdul Latif (n 32).[16]. 
The second is having dominant (the most influential) role in making the crime happen. One with high position/function and authority embedded in him may easily access to a regional program as previously discussed. In regional budgeting, the implementation of the regional budget along with its responsibility by a party with a high position that directly deals with the program is the Regional Mayor. On the other hand, the mechanism of regional budgeting up to its responsibility involves many parties, including Regional Secretary, SKPD, DPRD, and the other functionaries. The functionary/organizer such as Regional Mayor, the head of DPRD or another stakeholder may control (influence) many pertinent parties to follow their orders due to their position or by bribing them. With such access, they may see which programs are potential to gain more profits for their personal and other interests.

Additionally, the regional mayor has a strategic position to accept a bestowal such as a bribe or gratification from the third party, given his influential position, including the process of procurement for regional government. Besides, to determine the dominant role is not always related to a high position. The dominant role may also be identified by constructing a corruption to be investigated. The investigation is the first step to follow up the evidence found from inquiry and based on the result of the investigation, the real culprit of a crime can be identified based one-two legal (initial) evidence. ${ }^{36}$ By constructing a corruption case, each of the corruptors' roles is then identified.

The last criterion is the capability to stop or continue the crime. The actor may stop any potential activities from being corrupted since he/she has the authority to do so with his/her dominant power/role. Otherwise, due to particular purposes for personal or private interests, the party decides to continue/let the corruption happen and takes benefits from the crime. Recently, corruptors in Indonesia are mostly dominated by regional mayors. Based on data by Kompas, during 2018, 29 mayors were found as corruptors and had been caught by KPK, either in governor, regent, or mayor levels. The list is as follow: Rita Widyasari, the the non-active Mayor

${ }^{36}$ Ahmad Yunus, 'Penetapan Pelaku Tindak Pidana Korupsi Sebagai Justice Collaborator' (2017) 24 Simbur Cahaya.[4759]. 
of Kutai Kertanegara; Taufiqurrahman, the non-active Mayor of Nganjuk; Rudy Erawan, the non-active Mayor of East Halmahera; Mohmammad Yahya Fuad, Mayor of Kebumen; Abdul Latif, Mayor of Hulu Sungat Tengah; Zumi Zola, the non-active Governor of Jambi; Nyono Suharli Wihandoko, the Mayor of Jombang; Marianus Sae, the Mayor of Ngada; Imas Aryumningsih, the Mayor of Subang; Mustafa, the Mayor of Central Lampung; Adriatma Dwi Putra; the Mayor of Kendari; Abu Bakar, the Mayor of West Bandung; Dirwan Mahmud, the Mayor of South Bengkulu; Mustofa Kama Pasa, the Mayor of Mojokerto; Agus Feisal Hidayat, the Mayor of South Buton; Tasdi, the Mayor Purbalingga; Syahri Mulyo, the Mayor of Tuluagung; Samanhudi Anwar, the Mayor of Blitar; Irwandi Yusuf, the governor of Aceh; Ahmadi, the Mayor of Bener Meriah; Sunjaya Purwadisastra, the Mayor of Cirebon; Zainudin Hasan, the Mayor of South Lampung; Setiyono, the Mayor of Pasuruah; Rendra Kresna, the Mayor of Malang; Neneng Hassanah Yasin, the Mayor of Bekasi; Pangonal Harahap; the Mayor of Labuhanbatu; Remigo Yolando Berutu, the Mayor of PakPak Bharat; Ahmad Marzuki, the Mayor of Jepara; and the last is Irvan Rivano Muchtar, the Mayor of Cianjur. ${ }^{37}$

One case of corruption that has been inkracht is Zumi Zola, the non-active Governor of Jambi. He was sentenced by six years in prison and fine IDR 500 million with subsidiary at three months, as well as an additional sanction which is a revocation of his political right for five years after he completed his primary criminal sentence. Zumi Zola is found obtaining a gratification in the form of money IDR 37.477.000,- ; USD 173.300 and SGD 100.000 and he was found bribing 53 members of 2014-2019 Regional Assembly of Jambi. The total bribe was IDR 16,34 billion to the regional assembly of Jambi to make them approve the Draft of Regional Regulation of Regional Budgeting between 2017 and 2018 period as Perda APBD 2017 and APBD 2018. Zumi Zola was found violating Article $12 \mathrm{~B}$ of UU PTPK jo. Article 55 subsection (1) $1^{\text {st }}$ jo. Article 65 subsection (1) of Criminal

\footnotetext{
${ }^{37}$ Akbar Bhayu Tamtomo, 'Infografik: 29 Kepala Daerah Terjerat Kasus Korupsi Sepanjang 2018' (Kompas, 2018) <https://nasional.kompas.com/read/2018/12/27/08512001/infografik-29kepala-daerah-terjerat-kasus-korupsi-sepanjang-2018> accessed 27 February 2019.
} 
Code, and Article 5 subsection (1) letter an of UU PTPK jo. Article 55 subsection (1) $1^{\text {st }}$ jo. Article 65 subsection (1) of the Criminal Code. Toward Zumi Zola's appeal as justice collaborator, the Judge Committee of Corruption Court in Central Jakarta refused the appeal to become justice collaborator. The committee agreed to the public prosecutor of KPK to not approve a defendant as justice collaborator. The public prosecutor of KPK argued that the information by Zumi Zola in the process of investigation and court session was not significant to reveal either the culprit or the other corruptions, and Zumi Zola is one that should be most responsive to the case, both as the recipient of gratification and as the bestower of bribe that dealt with 2017 and 2018 regional budget (i.e., APBD). ${ }^{38}$

From the case of Zumi Zola, it seems that his function as governor makes him have a dominant/influential role in constructing the regional budget of Jambi. He knows the process of drafting APBD up to the implementation of APBD. Zumi Zola was capable of stopping his crime of bribing the regional assembly of Jambi in case that he had no personal interests out of what was supposed to be on his authority as governor.

\section{Conclusion}

Corruption is classified into an extraordinary crime, and it is often found as an organized crime that involves many parties. Therefore, the attempt to overcome such crime should be extraordinary as well. Recently, corruption often happens in the financial management of regional government setting that involves many parties in regional government. One attempt to overcome the corruption as applied on UNCAC 2003 is by utilizing justice collaborator to uncover the chain of the crime. Justice Collaborator is those who did a crime -but the primary actor- and they are willing to cooperate with law enforcers to unlock the chain of corruption they have done. Hence, to determine justice collaborator, it needs particular criteria of how the primary culprit plays his role in corruption. In case of identifying the procedures of how corruption

\footnotetext{
${ }^{38}$ Abba Gabrillin, 'Sepakat Dengan Jaksa, Hakim Tolak Permohonan "Justice Collaborator" Zumi Zola' (Kompas, 2018) <https://nasional.kompas.com/read/2018/12/06/13332801/sepakatdengan-jaksa-hakim-tolak-permohonan-justice-collaborator-zumi-zola> accessed 4 March 2019.
} 
happens in the financial management of regional government, it concludes that someone is identified as the primary culprit of corruption in the financial management of regional government if he/she meets several criteria, as follow.

1. Having a high position;

2. Having a dominant (influential) role in making the corruption happen; and/or

3. Capable of stopping or continuing the crime.

\section{Bibliography}

Abba Gabrillin, 'Sepakat Dengan Jaksa, Hakim Tolak Permohonan "Justice Collaborator” Zumi Zola' (Kompas, 2018) < https://nasional.kompas.com/ $\mathrm{read} / 2018 / 12 / 06 / 13332801 /$ sepakat-dengan-jaksa-hakim-tolak-permohonanjustice-collaborator-zumi-zola> accessed 4 March 2019.

Abdul Latif, Hukum Administrasi Dalam Praktik Tindak Pidana Korupsi (Prenada Media Group 2014).

Ahmad Rifai Rahawarin, 'Delik Penyertaan Dalam Tindak Pidana Korupsi Ditinjau Dari Perspektif Pemberantasan Korupsi Di Papua (Study Kasus Nomor: 69/ Tipikor/2013/PN-JPR)' (2014) 4 Legal Pluralism.

Ahmad Yunus, 'Penetapan Pelaku Tindak Pidana Korupsi Sebagai Justice Collaborator' (2017) 24 Simbur Cahaya.

Akbar Bhayu Tamtomo, 'Infografik: 29 Kepala Daerah Terjerat Kasus Korupsi Sepanjang 2018' (Kompas, 2018) <https://nasional.kompas.com/ $\mathrm{read} / 2018 / 12 / 27 / 08512001 /$ infografik-29-kepala-daerah-terjerat-kasuskorupsi-sepanjang-2018> accessed 27 February 2019.

Alfitra, Modus Operandi Pidana Khusus Di Luar KUHP (Korupsi, Money Laundering Dan Trafficking) (Raih Asa Sukses 2014).

Anti Corruption Clearing House Komisi Pemberantasan Korupsi, 'Tindak Pidana Korupsi Berdasarkan Instansi' (Anti Corruption Clearing House Komisi Pemberantasan Korupsi, 2016) <https://acch.kpk.go.id/id/statistik/tindakpidana-korupsi/tpk-berdasarkan-instansi $>$ accessed 25 February 2018.

Barda Nawawi Arif, Bunga Rampai Kebijakan Hukum Pidana (Citra Aditya Bakti 1996).

Basir Rohrohmana, 'Penerapan Ajaran Turut Serta Dalam Tindak Pidana Korupsi' (2017) 32 Yuridika. 
Endi Nurindra Putra, 'Penerapan Ajaran Penyertaan Dalam Tindak Pidana Kecelakaan Lalu Lintas Yang Dilakukan Oleh Anak (Studi Perkara Di Wilayah Hukum Pengadilan Negeri Purworejo)' (2015) 1 Jurnal Idea Hukum.

Firman Wijaya, Whistle Blower Dan Justice Collaborators Dalam Perspektif Hukum (Wedatama Widya Sastra 2014).

H. Abdul Latif, Hukum Administrasi Dalam Praktik Tindak Pidana Korupsi Edisi Kedua (Kencana 2014).

H. Sadjijono, Bab-Bab Pokok Hukum Administrasi (LaksBang Pressindo 2011).

Haryono Umar, Corruption the Devil (Universitas Trisakti Jakarta 2016).

Ike Indra Agus Setyowati, 'Pembantuan Dan Penyertaan (Deelmining) Dalam Kasus Perkosaan Anak' (2018) 1 Media Iuris <https://e-journal.unair.ac.id/ $\mathrm{MI} /$ article/view/8831>.

Lilik Mulyadi, Perlindungan Hukum Whistleblower and Justice Collaboration Organized Crime (Alumni 2015).

Mudzakkir, 'Penyelesaian Kejahatan Yang Termasuk White Collar Crime' (1994) 2 Jurnal Hukum.

Nur Basuki Minarno, 'Pembuktian Gratifikasi Dan Suap Dalam Tindak Pidana Korupsi’ (2005) 20 Yuridika.

—_, Penyalahgunaan Wewenang Dan Tindak Pidana Korupsi Dalam Pengelolaan Keuangan Daerah (Laksbang Mediatama 2009).

Pilliphus M. Hadjon, 'Tentang Wewenang' (1997) 7 Yuridika $<$ https://e-journal. unair.ac.id/YDK/article/view/5769>.

Sekretariat Nasional Forum Indonesia untuk Transparansi Anggaran, 'Korupsi (Sudah) Terjadi Sejak Perencanaan Anggaran' (Seknas Fitra) <http:// seknasfitra.org/korupsi-sudah-terjadi-sejak-perencanaan-anggaran/> accessed 25 February 2019.

Shinta Agustina, Penjelasan Hukum Unsur Melawan Hukum: Penafsiran Unsur Melawan Hukum Dalam Pasal 2 Undang-Undang Pemberantasan Tindak Pidana Korupsi (Lembaga Kajian dan Advokasi Independensi Peradilan 2016).

Susan Rose-Ackerman, Korupsi Dan Pemerintahan (Translator: Toenggoel P. Siagian ed, Pustaka Sinar Harapan 2010).

HOW TO CITE: Nurma Rosyida, Kadek Deddy Permana Artha and Lintang Yudhantaka, 'The Position of Justice Collaborator to Reveal Corruption in Financial Management of Regional Government' (2020) 35 Yuridika. 
--This page is intentionally left blank-- 